\title{
Recognition of Isolated Handwritten Characters of Gurumukhi Script using Neocognitron
}

\author{
Dharamveer Sharma \\ Assistant Professor, \\ Department of Computer Science, \\ Punjabi University, Patiala
}

\author{
Ubeeka Jain \\ M. Tech. (Computer Science), \\ Department of Computer Science, \\ Punjabi University, Patiala
}

\begin{abstract}
This paper presents the development of Gurumukhi character recognition system of isolated handwritten characters by using Neocognitron at the first time. Well- known neocognitron artificial neural network is chosen for its fast processing time and its good performance for pattern recognition problems. Here we have found the recognition accuracy of both learned and unlearned images of characters. Learned images have recognition accuracy as $91.77 \%$ and unlearned images have recognition accuracy as $93.79 \%$. The overall recognition accuracy for both learned and unlearned Gurmukhi characters are $92.78 \%$. This confirms that the proposed neocognitron artificial neural network approach is suitable for the development of isolated handwritten characters of Gurumukhi script.
\end{abstract}

Keywords: OCR, Gurmukhi Script, Neocognitron, isolated handwritten character recognition.

\section{INTRODUCTION}

For the past decades, there has been increasing interest among researchers in problem related to the machine simulation of the human reading process. Intensive research has been carried out in this area with a large number of technical papers and reports in the literature devoted to character recognition. This subject has attracted vast research interest, not only because of the very challenging nature of the problem but also because it provides the means for automatic processing of large volumes of data in reading, office automation, and also in real world application for the input to computers where people do not know how to type, also used for reducing time to re-printed documents. Character recognition systems can contribute extremely to the advancement of the automation process and can improve the interaction between man and machine in many applications.

The relevance of the task, implementing an OCR for paper reading, is that it can reduce the load on financial and time resources in the printing industry. Currently, in paint paper processing, the amount of encoding is a labor-intensive step, which requires many persons to print each paper (redundancy is used for accuracy). Automating this task can dramatically reduce the workload of menial labor and correspondingly, reduce the cost of print paper processing. Furthermore, a human operator generally takes more time to print paper while an automated system should be able to offer better speeds.

Over the past decades, many different methods have been explored by a large number of scientists to recognize characters. A variety of approaches have been proposed and tested by researchers in different parts of the world, including statistical methods and many papers have been concerned with the recognition of Latin, Chinese and Japanese characters, no research has been achieved towards the automatic recognition of Gurumukhi characters using Neocognitron.

The problem of Gurumukhi character recognition is more difficult than other languages in respects to the variability of writing style, both between different writers and between separate examples from the same writer overtime, Another problem is similarity of some characters, Low quality of text images, unavoidable presence of background noise and various kinds of distortions (such as poorly written, degraded, or overlapping characters) can make the recognition process even more difficult.

In this paper, neocognitron artificial neural network has been used for the feature extraction process. After each character is extracted, the features are fed to neocognitron artificial neural network engine. Then the output of engine is dispatched to the decision making process.

The rest of the paper has been organized as: section 2 covers features of Gurmukhi script, section 3 introduces the neocognitrons, feature extraction and classification is given in section 4 , section 5 explain the results of the experimentation and section 6 contains conclusion of the research work and future scope.

\section{FEATURES OF GURUMUKHI SCRIPT}

The Gurumukhi alphabet was devised during the 16th century by Guru Nanak, the first Sikh guru, and popularized by Guru Angad, the second Sikh guru. It was modeled on the Landa alphabet. The name Gurumukhi means "from the mouth of the Guru".

Gurumukhi alphabet consists of 41 consonants, 12 vowels, 10 numerals and some other symbols as shown in following figures. Gurumukhi is written from left to right. Since the proposed application area provides letters in an isolated form.

Besides these, some characters in the form of half characters are present in the feet of characters.

- Writing style is from left to right.

- In Gurumukhi, There is no concept of upper or lowercase characters.

- A line of Gurumukhi script can be partitioned into three horizontal zones namely, upper zone, middle zone and lower zone.

- Consonants are generally present in the middle zone. The upper and lower zones may contain parts of vowel modifiers and diacritical markers. These zones are shown 
in following figure as:

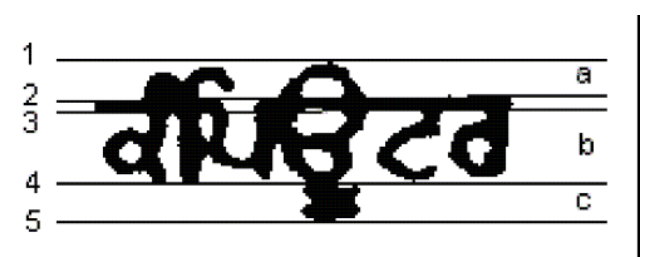

Figure 1: a) Upper zone from line number 1 to 2, b) Middle Zone from line number 3 to 4 , c) lower zone from line number 4 to 5

In Gurumukhi Script, most of the characters, as shown in above Figure, contain a horizontal line at the upper of the middle zone. This line is called the headline. The characters in a word are connected through the headline along with some symbols as i, I, a etc. The headline helps in the recognition of script line positions and character segmentation.

The segmentation problem for Gurumukhi script is entirely different from scripts of other common languages such as English, Chinese, and Urdu etc. In Roman script, windows enclosing each character composing a word do not share the same pixel values in horizontal direction. But in Gurumukhi script, as shown in Fig 1(e), two or more characters/symbols of same word may share the same pixel values in horizontal direction.

This adds to the complication of segmentation problem in Gurumukhi script. Because of these differences in the physical structure of Gurumukhi characters from those of Roman, Chinese, Japanese and Arabic scripts, the existing algorithms for character segmentation of these scripts does not work efficiently for handwritten Gurumukhi script.

\section{INTRODUCTION OF NEOCOGNITRON}

The Neocognitron is a hierarchical multilayered neural network proposed by Professor Kunihiko Fukushima. It has been used for handwritten character recognition and other pattern recognition tasks. The neocognitron is inspired from the model proposed by Hubel \& Wiesel in 1959. They found two types of cells in visual primary cortex called simple cell and complex cell, and also proposed a cascading model of these two types of cells. The neocognitron is a natural extension of these cascading models. In the neocognitron, which consists of two types of cells called $\boldsymbol{S}$-cell and $\boldsymbol{C}$-cell, the local features are extracted by Scells, and deformation of these features, such as local shifts, are tolerated by C-cells. Local features in the input are integrated gradually and classifying in the higher layers.

An Artificial Neural Network (ANN), usually called "Neural Network" (NN), is a mathematical model or computational model that tries to simulate the structure and/or functional aspects of biological neural networks. It consists of an interconnected group of artificial neurons and processes information using a connectionist approach to computation. In most cases an ANN is an adaptive system that changes its structure based on external or internal information that flows through the network during the learning phase. Neural networks are non-linear statistical data modeling tools. They can be used to model complex relationships between inputs and outputs or to find patterns in data.

There is no precise agreed-upon definition among researchers as to what a neural network is, but most would agree that it involves a network of simple processing elements (neurons), which can exhibit complex global behavior, determined by the connections between the processing elements and element parameters. The original inspiration for the technique came from examination of the central nervous system and the neurons (and their axons, dendrites and synapses) which constitute one of its most significant information processing elements.

In a neural network model, simple nodes (called variously "neurons", "neurodes", "PEs" ("processing elements") or "units") are connected together to form a network of nodes - hence the term "neural network."

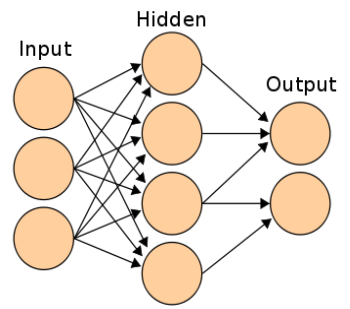

Figure 2: General Model of Neural Network

Artificial neural network architectures such as backpropagation tend to have general applicability. We can use a single network type in many different applications by changing the network's size, parameters, and training sets. In contrast, the developers of the neocognitron set out to tailor architecture for a specific application: recognition of handwritten characters. Such a system has a great deal of practical application, although, judging from the introductions to some of their papers, Fukushima and his coworkers appear to be more interested in developing a model of the brain.

At present there are many different versions of the neocognitron. Two original basic versions proposed by Professor Fukushima differ in used learning principle mainly:

- learning without a teacher

- learning with a teacher

The first version of the neocognitron was based on the learning without a teacher. This version is often called self-organized neocognitron. The main advantage of neocognitron is its ability to recognize correctly not only learned patterns but also patterns which are produced from them by using of partial shift, rotation or another type of distortion. Our system is a neocognitron which recognizes handwritten characters of Gurumukhi script.

\section{FEATURE EXTRACTION AND CLASSIFICATION}

The performance of a character recognition system depends heavily on what features are being used. Selection of a feature extraction method is probably the single most important factor in achieving high recognition. The key issue of any recognition system is feature extraction. Feature extraction abstracts high level information about individual patterns to facilitate recognition. Selection of feature extraction method is probably the single most important factor in achieving high recognition performance. 
In this research, neocognitron artificial neural network has been used to extract feature from Gurumukhi Character images and then classified these features.

The neocognitron performs classification of input through a succession of functionally equivalent stages. Each stage extracts appropriate features from the output of the preceding stage and then forms a compressed representation of those extracted features. The compressed representation preserves the spatial location of the extracted features and becomes the input to the following stage. Classification is achieved by steadily extracting and compressing feature representations until the input is reduced to a vector. Each element of which corresponds to a similarity measure between the input and the different classes of input that the neocognitron has been trained to classify, following figure 1(h)(i) shows the structure of the neocognitron as a sequence of stages composed by two layers:

S-layer, composed by S-cells, responsible for the feature extraction; and C-layer composed by C-cells, responsible for the tolerance of shape and position. These cells at the same cellplane are identical, regardless of their position. Each S-cell is connected to a rectangular region of cells (known as receptive field), the receptive fields as shown in following figure 1(h)(ii)) of the S-cells in the array uniformly cover the input cell plane. In any S-plane, the connection strength between each cell and its receptive field is replicated. This ensures a translationally invariant response to features in the input cell plane.

The C-cell planes (C-planes) showed in figure 1(h) (i) compress the activity of the previous S-planes into a smaller representation. In doing this, the c-cells provide a degree of translational invariance to the responses of the preceding S-cells. Ultimately this compression of activity reaches the stage where the input pattern is represented by a set of single C-cells, each corresponding to an input class that the neocognitron has been trained to recognize. At this stage, the $\mathrm{C}$-cell with the highest activity represents the class to which the input belongs.

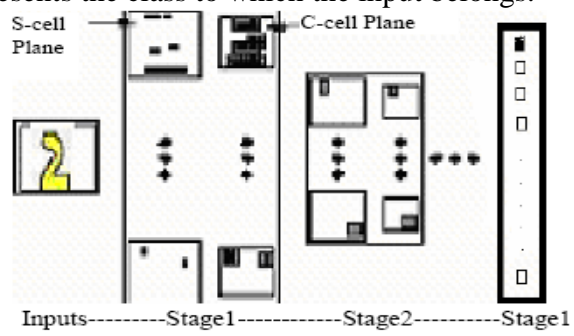

(a)

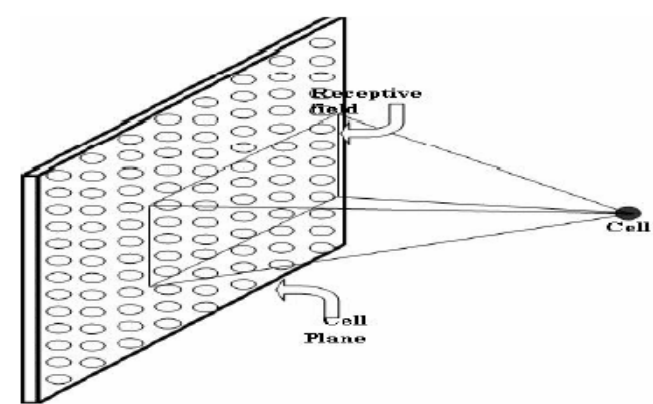

Figure 3: (a) The basic structure of the Neocognitron. (b) The general structure of $S$ and $C$ cell planes.

\subsection{Neocognitron training}

During the training phase, it is defined which features will be recognized by each cell plane of a given S-layer. The training process starts from the first level, and goes through, until all the levels are trained. First, an input pattern is presented to the network, many cells can be activated. At this moment, all the activated cells are verified in order to select the most strongly activated cell, which is considered as the winner. When the winner is selected, its weight is reinforced. After reinforcement, the winner-cell can recognize the corresponding feature. If all cells in a cell-plane are identical, a cell-plane with all cells identical to the winner-cell (seed cell) is created and it becomes a valid cell-plane, or a trained cell-plane. The procedure is repeated, taking into account that the winner-cell cannot be activated coincidently with any previously trained cell-plane. When the coincidence occurs the next strongest cell is to be selected as the winner. After presenting the input patterns many times, and detecting any new feature, the training of a given layer is completed, and the algorithm continues to the next stage, until the training of all the stages is completed.

\subsection{Creation of training data form:}

Training data form has been created to make a database of isolated handwritten characters. This is shown by the following figure. The database is created of isolated handwritten characters image collected from 300 numbers of writers and consists 50 numbers of individual characters of Gurumukhi scripts. We used 150 forms for training and 150 forms for testing. Following is an image of form:

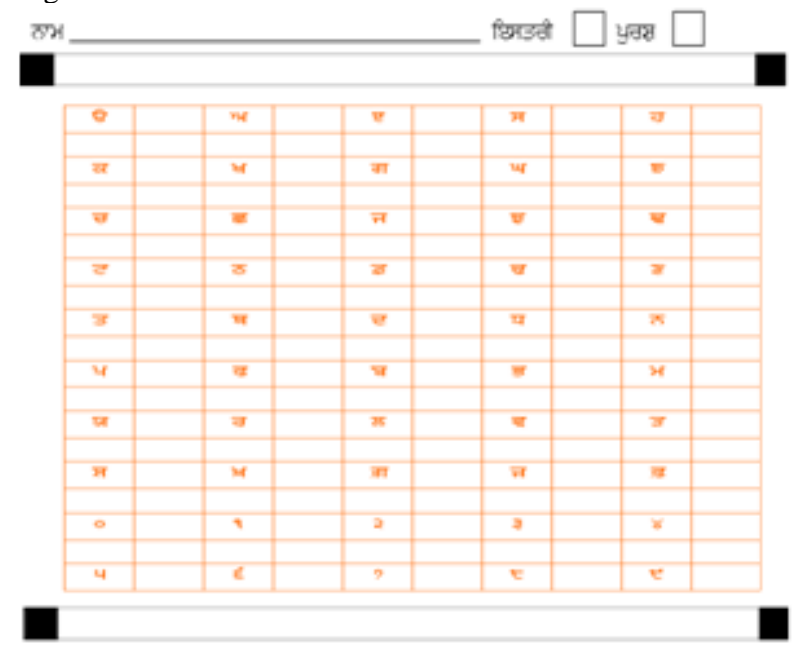

Figure 4: form used for collection of database.

From the above form we extracted the characters by using the four reference points shown all the four corners of above form. From this we created horizontal and vertical profiles of isolated characters and stored height and width of each character. We have used unsupervised training system which knows about character and makes the feature vector for each character and stored the images of isolated handwritten characters of Gurumukhi characters.

Here we have some samples of training data form filled by the different writers as shown below: 


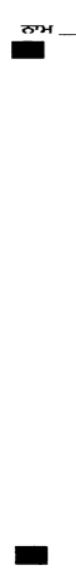
टिमउती $\square$ युवस $\square$

6

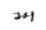

2

$$
\rightarrow
$$
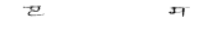

च

3

य 2

ज $\Rightarrow$

$\Rightarrow \quad \Rightarrow$

य 2

Figure 5: Samples of collected data

Some samples of the handwriting are given in table 1 .

Table 1: Sample Set for Gurumukhi Characters

\begin{tabular}{|c|c|c|c|c|c|}
\hline $\begin{array}{c}\text { Original } \\
\text { Gurumukhi } \\
\text { Characters }\end{array}$ & $\begin{array}{c}\text { Writer } \\
1\end{array}$ & $\begin{array}{c}\text { Writer } \\
2\end{array}$ & $\begin{array}{c}\text { Writer } \\
\mathbf{3}\end{array}$ & $\begin{array}{c}\text { Writer } \\
4\end{array}$ & $\begin{array}{c}\text { Writer } \\
5\end{array}$ \\
\hline$G$ & $\beta$ & $f$ & $\beta$ & $\sqrt{3}$ & $\beta$ \\
\hline मf & $m$ & 77 & on & $m$ & 8 \\
\hline प्ट & 2 & $\varepsilon$ & 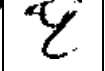 & 2 & $\varepsilon$ \\
\hline म & 5 & 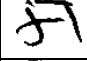 & म & $\gamma$ & H \\
\hline J & $j$ & $J$ & $-\sqrt{ }$ & $J$ & $J$ \\
\hline व & 2 & 2 & 2 & $\bar{\partial}$ & $q$ \\
\hline ધ & $z$ & $E r$ & 4 & $k 1$ & मे \\
\hline गा & $\partial 1$ & $\sqrt{1}$ & 21 & Ji & 71 \\
\hline यঙ & 24 & $24 \pi$ & $2 \pi$ & 24 & 24 \\
\hline इ & $\$$ & 2 & 5 & 5 & 5 \\
\hline च & 8 & J & 8 & $\Sigma$ & 3 \\
\hline ह & 8 & 8 & $\varepsilon$ & \& & 8 \\
\hline त & 7 & F & $N$ & 7 & 7 \\
\hline ₹ & 8 & 2 & पू & $\check{2}$ & タ \\
\hline हृ & $\bar{z}$ & 미 & पृ & $E$ & $\varepsilon$ \\
\hline ट & 2 & ट & 2 & $\Sigma$ & $c$ \\
\hline$\delta$ & $z$ & $c$ & 3 & $\tau$ & ろ \\
\hline उ & 3 & 3 & 3 & 3 & 3 \\
\hline
\end{tabular}

\begin{tabular}{|c|c|c|c|c|c|}
\hline $\begin{array}{c}\text { Original } \\
\text { Gurumukhi } \\
\text { Characters }\end{array}$ & $\begin{array}{c}\text { Writer } \\
1\end{array}$ & $\begin{array}{c}\text { Writer } \\
2\end{array}$ & $\begin{array}{c}\text { Writer } \\
3\end{array}$ & $\begin{array}{c}\text { Writer } \\
4\end{array}$ & $\begin{array}{c}\text { Writer } \\
5\end{array}$ \\
\hline ह & 2 & E & 8 & 2. & $\vec{E}$ \\
\hline$\Sigma$ & 5 & $\bar{\varepsilon}$ & $\bar{Z}$ & $\bar{\varepsilon}$ & $\bar{c}$ \\
\hline 3 & 3 & 3 & 5 & 3 & 3 \\
\hline घ & $G$ & $\bar{E}$ & घ & 4 & स \\
\hline 己 & 2 & E & 2 & $\bar{z}$ & 2 \\
\hline य & च & प & य & च & $\overline{4}$ \\
\hline চ & $\pi$ & T) & 5 & $\bar{\lambda}$ & ढ) \\
\hline ૫ & 24 & $\tau$ & $2 T$ & 4 & 4 \\
\hline ढ & $z$ & छ & $\zeta$ & $\Sigma$ & $\vec{G}$ \\
\hline घ & d & ब & $घ$ & ता & घ \\
\hline उ & 3 & 3 & 3 & 3 & 3 \\
\hline भ & भ & H & $n^{\prime}$ & 2 & 4 \\
\hline ज & ज & F & $\pi$ & त & F \\
\hline ठ & $\partial$ & $\partial$ & $\bar{J}$ & $\partial$ & $\exists$ \\
\hline ম & $\overline{8}$ & $\bar{c}$ & 8 & $\xi$ & $\bar{B}$ \\
\hline ह & $z$ & $\underline{E}$ & $\bar{\varepsilon}$ & $\sum$ & $\varepsilon$ \\
\hline 3 & 藏 & $\overline{3}$ & 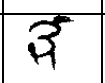 & $\sqrt{3}$ & 3 \\
\hline म़ & $\bar{\gamma}$ & मा & 1 & म & म \\
\hline tq & $z$ & यद & 4 & 4 & 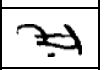 \\
\hline गा & . & ग़ & ग1 & गा & ?ा \\
\hline त़ & 7 & TT & तT & ? & $?$ \\
\hline ढ & द & $\bar{z}$ & ? & $E$ & द \\
\hline$\circ$ & 0 & 0 & 0 & 0 & 0 \\
\hline 9 & 2 & 8 & 9 & 2 & 2 \\
\hline 2 & 2 & 2 & 2 & 2 & 2 \\
\hline 3 & 3 & 3 & ३ & 3 & $\beta$ \\
\hline$\gamma$ & $\gamma$ & $\gamma$ & $\gamma$ & $\gamma$ & $\gamma$ \\
\hline 4 & 4 & $\pi$ & 21 & $4^{\prime}$ & 4 \\
\hline$\varepsilon$ & $\varepsilon$ & $\varepsilon$ & $\varepsilon$ & $\varepsilon$ & $\varepsilon$ \\
\hline
\end{tabular}




\begin{tabular}{|c|c|c|c|c|c|}
\hline $\begin{array}{c}\text { Original } \\
\text { Gurumukhi } \\
\text { Characters }\end{array}$ & $\begin{array}{c}\text { Writer } \\
1\end{array}$ & $\begin{array}{c}\text { Writer } \\
2\end{array}$ & $\begin{array}{c}\text { Writer } \\
\mathbf{3}\end{array}$ & $\begin{array}{c}\text { Writer } \\
4\end{array}$ & $\begin{array}{c}\text { Writer } \\
5\end{array}$ \\
\hline$?$ & 9 & 9 & $?$ & 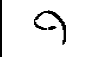 & 7 \\
\hline$\tau$ & $\varepsilon$ & $\tau$ & 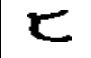 & $r$ & $\tau$ \\
\hline$t$ & $\Sigma$ & $\alpha$ & ك & 2 & $2^{5}$ \\
\hline
\end{tabular}

\section{EXPERIMENTAL RESULTS}

In this paper a system to recognize isolated handwritten characters in Gurumukhi characters has been developed. In this images of isolated handwritten characters are provided as input. Then feature extraction methods extract the features of the characters and finally, classifiers identity the characters using the features extracted by feature extractors. Neocognitron is used as a feature extractor and classifier.

An annotated sample image database of isolated handwritten characters in Gurumukhi script has been prepared. The database contains name of source image with its extension i.e. .tiff, size (height and width) of image and character value of the image. For storage of image data XML format has been used. We have experimented the system on total 15000 images of Gurumukhi characters contained in the database. We have used 7500 images to train or learn the system and 15000 images to test the system out of which 7500 are learned or trained images and rest 7500 are unlearned images. Recognition accuracy is given by the following table 1.2.

\subsection{Confusion Matrix for Gurumukhi Alphabets}

Confusion matrix shows how many times one character of Gurumukhi confused with other character. The recognition accuracy is obtained by dividing the correctly recognized characters to total number of character images which are actually present in the database.

The matrix given in Table 1.2 represents the confusion matrix for Gurmukhi character set. Some of the most confusing pairs for characters are $\theta$ with घ $(2.00 \%)$, मr with $u(9.48 \%)$, म with मन $(2.14 \%)$, उ with ठ $(3.30 \%)$, गा with .ग $(3.50 \%)$, ur with भr $(4.33 \%)$, ठ with $\delta(2.50 \%)$, उ with उ $(2.16 \%)$, उ with इ $(1.10 \%)$, घ with $\forall(2.25 \%)$ घ with घ $(2.25 \%)$, य with 4 ( $3.65 \%)$, ढ with . $(3.23 \%)$, घ with $\theta(6.80 \%)$, ज with r $(3.42 \%)$, उ with J $(3.32 \%)$, ম with $\delta(4.28 \%)$, ह with $\theta$ $(4.00 \%)$, इ with उ $(3.50 \%)$, म with म $(4.89 \%)$, .ा With गा $(6.50 \%)$, ढ with ढ $(6.50 \%)$, य with $4(5.50 \%)$, ว with 9 $(9.50 \%)$.

The confusion between character recognition is due to shape similarity of the characters. Handwritten data increases the confusion further. The characters with higher recognition rates are ० $(100.00 \%), 8(100.00 \%)$, व $(96.27 \%)$, च $(95.80 \%)$, गा $(95.68 \%)$, ह $(95.66 \%)$ and the characters with least accuracy are as $भ$ r $(82.35 \%)$, ढ (86.50\%), २ (87.00\%), य (87.31\%). This is evident from table 2 .

Here we have found the recognition accuracy of both learned and unlearned images of characters. Learned images have recognition accuracy as $91.77 \%$ and unlearned images have recognition accuracy as $93.79 \%$. The average recognition accuracy for both learned and unlearned Gurmukhi characters are $92.78 \%$ which is shown by the following table named as confusion matrix.

Table 2: Confusion matrix for Gurmukhi Alphabet

\begin{tabular}{|c|c|c|c|c|c|c|c|c|c|}
\hline \multirow{2}{*}{$\begin{array}{c}\text { Character } \\
\theta\end{array}$} & \multirow{2}{*}{$\begin{array}{c}\begin{array}{c}\text { Recognized } \\
\text { As }\end{array} \\
\text { Ө } 94.71 \%\end{array}$} & \multicolumn{8}{|c|}{ Confused with characters } \\
\hline & & * $1.30 \%$ & इ $0.40 \%$ & ㄹ $1.59 \%$ & घ $2.00 \%$ & & & & \\
\hline m & भr $82.35 \%$ & ur $9.48 \%$ & Н $4.48 \%$ & ज $3.69 \%$ & & & & & \\
\hline प & द $93.05 \%$ & ₹ $2.15 \%$ & ट $2.00 \%$ & z $1.20 \%$ & ㄹ $1.30 \%$ & $\varepsilon 0.30 \%$ & & & \\
\hline म & म $92.29 \%$ & स $1.20 \%$ & य $2.28 \%$ & บ $0.30 \%$ & H $1.00 \%$ & ज $0.29 \%$ & म $2.14 \%$ & गा $0.50 \%$ & \\
\hline J & J $95.00 \%$ & च $0.50 \%$ & б $0.70 \%$ & 兀 $3.30 \%$ & २ $0.50 \%$ & & & & \\
\hline$\alpha$ & व $96.27 \%$ & E $1.23 \%$ & e $1.50 \%$ & २ $1.00 \%$ & & & & & \\
\hline$\Psi$ & ч $91.53 \%$ & ur $0.20 \%$ & в $1.20 \%$ & य $1.70 \%$ & บ $2.50 \%$ & в $0.40 \%$ & Н $0.17 \%$ & צ $2.00 \%$ & $40.30 \%$ \\
\hline गा & गा $95.68 \%$ & म $0.52 \%$ & н $0.30 \%$ & .ा $3.50 \%$ & & & & & \\
\hline$u$ & u $94.82 \%$ & m $4.33 \%$ & $\forall 0.35 \%$ & ज $0.50 \%$ & & & & & \\
\hline 5 & $594.75 \%$ & ₹ $5.25 \%$ & & & & & & & \\
\hline$\theta$ & च $95.81 \%$ & व $0.75 \%$ & द $0.89 \%$ & z $0.40 \%$ & व $1.00 \%$ & त $0.50 \%$ & t $0.65 \%$ & & \\
\hline ह & ह $95.66 \%$ & ₹ $1.54 \%$ & च $1.00 \%$ & ह $1.50 \%$ & $\varepsilon 0.30 \%$ & & & & \\
\hline त & त $94.91 \%$ & म $0.33 \%$ & म $1.32 \%$ & क. $2.00 \%$ & च $1.44 \%$ & & & & \\
\hline
\end{tabular}




\begin{tabular}{|c|c|c|c|c|c|c|c|c|c|}
\hline Character & Recognized & & & Co & fused wit & charact & & & \\
\hline ₹ & ₹ $94.75 \%$ & प $1.50 \%$ & इ 0.75\% & इ $2.50 \%$ & ३ $0.50 \%$ & & & & \\
\hline द & द $92.50 \%$ & ㄹ $2.50 \%$ & प $3.00 \%$ & ¿ $1.50 \%$ & $\varepsilon 0.50 \%$ & & & & \\
\hline ट & ट $93.20 \%$ & प $3.00 \%$ & ट $1.50 \%$ & e $0.95 \%$ & в $1.35 \%$ & & & & \\
\hline б & б $92.50 \%$ & छ $1.50 \%$ & б $2.50 \%$ & б $2.00 \%$ & м 1.50\% & & & & \\
\hline उ & з $93.50 \%$ & з $2.50 \%$ & क $2.00 \%$ & इ $1.50 \%$ & з $0.50 \%$ & & & & \\
\hline ह & द $87.65 \%$ & ट $1.30 \%$ & ट $2.30 \%$ & ट $1.25 \%$ & e $2.00 \%$ & в $1.50 \%$ & च $2.50 \%$ & t $0.50 \%$ & $\{1.00 \%$ \\
\hline$\Sigma$ & ¿ $93.35 \%$ & प $3.00 \%$ & ट $2.00 \%$ & ह $0.78 \%$ & ह $0.67 \%$ & ع 0.20\% & & & \\
\hline उ & з $93.74 \%$ & उ $2.50 \%$ & क $2.16 \%$ & इ $1.10 \%$ & ३ $0.50 \%$ & & & & \\
\hline घ & в $89.31 \%$ & म $0.35 \%$ & ษ $2.25 \%$ & य $1.23 \%$ & บ $1.54 \%$ & в $2.25 \%$ & x $1.92 \%$ & ч $1.15 \%$ & \\
\hline e & e $91.70 \%$ & प $1.50 \%$ & छ $1.80 \%$ & ट $2.70 \%$ & द $1.50 \%$ & t $0.30 \%$ & $\{0.50 \%$ & & \\
\hline य & य $92.99 \%$ & म $0.33 \%$ & \} $1.50 \%$ & ज $0.33 \%$ & в $1.00 \%$ & บ $2.00 \%$ & 4 $1.85 \%$ & & \\
\hline б & б $92.91 \%$ & ट $0.78 \%$ & б $2.80 \%$ & б $1.76 \%$ & ल $1.75 \%$ & & & & \\
\hline ૫ & บ $90.27 \%$ & म $0.30 \%$ & ษ $1.20 \%$ & y $1.33 \%$ & в $1.30 \%$ & य $1.50 \%$ & ज $0.15 \%$ & н $0.30 \%$ & ч $3.65 \%$ \\
\hline ढ & द $90.29 \%$ & ह $1.42 \%$ & ट $1.30 \%$ & ह $1.00 \%$ & ट $1.30 \%$ & e $1.26 \%$ & . $3.23 \%$ & $\varepsilon 0.20 \%$ & \\
\hline घ & в $88.17 \%$ & ч $1.36 \%$ & в $2.50 \%$ & ๑ $6.80 \%$ & ૫ $1.17 \%$ & & & & \\
\hline व & क $90.50 \%$ & ₹ $4.00 \%$ & з $2.00 \%$ & इ $2.75 \%$ & ३ $0.75 \%$ & & & & \\
\hline H & н $90.15 \%$ & म $3.00 \%$ & ษ $1.40 \%$ & บ $1.20 \%$ & ज $1.30 \%$ & म $2.75 \%$ & ч $0.20 \%$ & & \\
\hline ज & ज $90.67 \%$ & r $3.42 \%$ & य $1.20 \%$ & u $2.86 \%$ & บ $1.85 \%$ & & & & \\
\hline ठ & б $90.48 \%$ & J $3.32 \%$ & в $1.70 \%$ & ट $0.50 \%$ & б $2.00 \%$ & e $0.60 \%$ & б $1.40 \%$ & & \\
\hline ম & ল 90.98\% & म $2.28 \%$ & ठ $4.28 \%$ & म $2.46 \%$ & & & & & \\
\hline ह & ㄹ $91.56 \%$ & 8 $4.00 \%$ & ट $1.42 \%$ & ह $1.22 \%$ & ¿ $1.60 \%$ & દ 0.20\% & & & \\
\hline इ & इ $88.00 \%$ & ₹ $4.00 \%$ & з $3.50 \%$ & б $2.00 \%$ & ३ $2.50 \%$ & & & & \\
\hline म & म $88.13 \%$ & म $4.89 \%$ & क्र $1.50 \%$ & в $0.86 \%$ & य $0.52 \%$ & \& $1.42 \%$ & н $2.68 \%$ & & \\
\hline tq & צ $90.25 \%$ & צ $3.00 \%$ & в $2.75 \%$ & บ $2.50 \%$ & ч $1.50 \%$ & & & & \\
\hline .गा & .ा $89.00 \%$ & गा $6.50 \%$ & मे $4.50 \%$ & & & & & & \\
\hline से & सד 92.00\% & न $8.00 \%$ & & & & & & & \\
\hline द & . $86.50 \%$ & ढ6.50\% & ट $4.50 \%$ & e $2.50 \%$ & & & & & \\
\hline ० & ○ $100.00 \%$ & & & & & & & & \\
\hline 9 & 9 $92.50 \%$ & 2 $7.50 \%$ & & & & & & & \\
\hline 2 & २ 87.00\% & 于 $3.50 \%$ & ₹ $9.50 \%$ & & & & & & \\
\hline ३ & з $91.00 \%$ & ₹ $1.25 \%$ & उ $1.50 \%$ & उ $2.75 \%$ & क $1.50 \%$ & इ $2.00 \%$ & & & \\
\hline 8 & $8100.00 \%$ & & & & & & & & \\
\hline 4 & $487.31 \%$ & ษ $1.30 \%$ & в $1.25 \%$ & य $3.30 \%$ & บ $5.50 \%$ & Н $1.14 \%$ & ष $0.20 \%$ & & \\
\hline$\varepsilon$ & $\varepsilon 91.70 \%$ & ट $1.30 \%$ & ह $2.20 \%$ & こ $1.10 \%$ & б $2.20 \%$ & ट $1.50 \%$ & & & \\
\hline 0 & م 90.50\% & $99.50 \%$ & & & & & & & \\
\hline$t$ & t $88.35 \%$ & च $4.65 \%$ & च $3.50 \%$ & e $2.50 \%$ & & & & & \\
\hline$\varepsilon$ & \{ $88.35 \%$ & द $3.50 \%$ & e $4.50 \%$ & च $3.65 \%$ & & & & & \\
\hline
\end{tabular}




\section{CONCLUSION AND FUTURE SCOPE}

In the system developed for recognition of isolated handwritten characters in Gurmukhi scripts images of isolated handwritten characters are provided as input. Neocognitron is used as a feature extractor and classifier. Characters having highest recognition accuracy are as $\circ(100.00 \%)$ (Digit 0$)$ and $\gamma$ (100.00\%). Characters having lowest recognition accuracy are as 2 r $(82.35 \%)$ and ह (86.50\%). Most confusing Pair is with ur $(9.48 \%)$.Learned images have recognition accuracy as $91.77 \%$ and unlearned images have recognition accuracy as $93.79 \%$. The overall recognition accuracy for both learned and unlearned Gurmukhi characters is $92.78 \%$.

The work presented in this paper can be further extended for on connected characters or words, by first segmenting the words and then recognizing the so obtained characters. In the present work only consonants, while lie in the middle zone and digits have been considered, in future vowels, lying in upper and lower zone and other half characters can also be used.

Possibility of adding probabilities to neocognitron may also be explored, by which system will classify characters with probabilities which can be used to accept or reject a recognized character for a particular class. This way recognition accuracy can be improved by reducing confused characters count.

\section{REFERENCES}

[1] K. Fukushima, "Neural Network Model for a mechanism of pattern recognition unaffected by shift in positionNeocognitron", IECE Japan, Vol.62-A, No.10, pp. 658665, April 1979.

[2] K. Fukushima, S. Miyake, and T. Ito, "Neocognitron: a neural network model for a mechanism of pattern recognition", IEEE Transactions on Systems, Man, and Cybernetics, Vol.65-C, No. 7, pp. 71 - 84, March 1987.

[3] K. Fukushima, "A neural network model for selective attention in visual Pattern recognition", BioZogica, Z Cybernetics, Vol. 55-1, No. 5, pp. 5-15, May 1986.

[4] K. Fukushima, "Neocognitron: A hierarchical neural network capable of visual pattern recognition", Neural Networks, Vol.1, No. 7, pp. 119-130, June 1988.
[5] B. Widrow, "Neural Networks for Adaptive Filtering and Adaptive Pattern Recognition ", IEEE Computer, Vol. 30D, No.7, pp. 25 - 39, March 1988.

[6] G. A. Carpenter and S.Gross berg, "A massively parallel architecture for a self-organizing neural pattern recognition machine", Computer vision, Graphics, and image processing, Vol. 20-C, No.3, pp. 15 - 25, March, 1988.

[7] G. A. Carpenter and Stephen Gross berg, "ART 2: selforganization of Stable category recognition codes for analog input patterns", AppZied Optics, Vol. 26, No. 23, pp. 4919 - 4930, December 1987.

[8] C. Vonder Malsburg, "Self-organization of orientation sensitive cells in the striate cortex", Kybemetik, Vol. 14, pp. 85-100, March 1973.

[9] M. M. Menon and K. G. Heinemann, "Classification of patterns using a Self -organizing neural network". Neural Networks, Vol. 1, pp 201-215, June 1988.

[10] Hubel and Wiesel, "Shape and arrangement of columns in the cat's striate cortex", Journal of Physiology, Vol.165, pp.559-567, April 1963.

[11] V. K. Govindan and A. P. Shivaprasad, "Character recognition - a survey", Pattern Recognition, Vol. 10 pp. 67-73, July 1990.

[12] R. P. Lippman, "An introduction to computing with neural networks", IEEE Transaction on Neural Network, Vol. 3, pp. 4-22, April 1987.

[13] R. P. Lippman, "Pattern classification using neural networks", IEEE Communication Magazine, Vol. 12, pp. 4744, November 1989.

[14] K. Fukushima, "Cognition: a self-organizing multi-layered neural network model", Biological Cyber, Vol. 20, pp. 121136, December 1975.

[15] K. Fukushima and S. Miyake, "Neocognitron: a new algorithm for pattern recognition tolerant of deformations and shifts in position", Pattern Recognition., Vol.15-6, pp. 455-469, March1982. 